The General Assembly, Vol. 2, No. 1, Jan. 2021

\title{
European Identity and the Challenges of Turkish Accession to the European Union
}

\author{
Sara Duodu
}

ABSTRACT In 2005, Turkey entered into negotiations for membership with the European Union. Turkey has been an important strategic ally to the European Union in the Middle East, explaining the mutual desire for closer ties between the two. While these negotiations showed promise early on, it has become increasingly apparent that Turkish accession to the European Union will not come easily, if at all. Officially, the European Union cites Turkey's shortcomings on issues such as human rights as the reason for the stall in negotiations. However, upon closer inspection, it is evident that there is more at play, particularly as the European Union has been inconsistent in their approach to addressing human rights violations. Member states such as Poland and Hungary, which have recent human rights violations, have not faced the same kind of condemnation that Turkey has from the leaders of the European Union. The reality is that the European Union is largely united by its shared Europeanness and Christianity. As a result, due to questions over Turkey's Europeanness and its large Muslim majority, the European Union is apprehensive to afford it full membership. It can be said that the European Union has maintained that Turkish accession is still possible in order to continue reaping the strategic benefits from close relations with Turkey.

Introduction

From its inception, the European Union (EU) set out to be an institution that would unite the entire continent of Europe. In its early form, the European Communities were made up of what was known as the Inner Six: Belgium, the Netherlands, Luxembourg, Italy, France, and West Germany. Since then, the EU has expanded to 27 member states across Western, Central, and Eastern Europe. As the European landscape continues to shift, questions are raised about what it means to be European and what makes a country eligible for EU membership. Current EU member states are combatting the rise of populism, while other European nations are vying for their spot in the EU. Most notable are the accession negotiations that have been taking place between the EU and Turkey since 2005. The current state of the European landscape means that Turkey's accession to the EU will continue to see heightened challenges as negotiations head into their fifteenth year.

This paper will set out to prove that the futility of Turkish accession negotiations has less to do with Turkey's inability to meet the requirements outlined by the EU and more to do with 
identity and culture, which are issues that were highlighted in the 2019 European Elections. To prove this assertion, this paper will analyze European identity and the myth of unity, the role of Christianity in the EU and the "othering" of Turkey, Turkey's role as a strategic ally for the EU, and recent trends in Europe that further explain why accession negotiations have stalled. It is important to note that the argument being made is not that Turkey is not partly responsible for the futility of accession negotiations. Indeed, Turkey bears some of that blame. However, the persistent narrative that Turkey inability's to gain EU membership is its own fault fails to acknowledge the inherent biases of the EU member states that made accession unlikely from the start.

\section{European Identity and the Myth of Unity}

Since the inception of the EU, there has been an active effort by member states to create a universal, homogenous European identity. This identity is rooted in the values of peace, freedom, democracy, and law and order. ${ }^{1}$ Seemingly, these values make up the basis of the EU and set the standard for the rest of Europe. The EU would ideally stand as a symbol of prosperity and cooperation, a model which the non-member European nations would strive to emulate. However, with 27 member states with varying histories and cultures, many Europeans are beginning to wonder whether it is at all possible for the EU to have a homogenous regional identity. ${ }^{2}$ Europe is marked by socioeconomic differences, with a clear divide between the richer and poorer EU nations. ${ }^{3}$ With countries undergoing different phases of marketization and financial crises across the Union, richer member states face the question of whether the relationship remains mutually beneficial if funds are constantly being appropriated to struggling nations that provide little in return. ${ }^{4}$ This socioeconomic divide is one of the issues that demonstrates how the Union's players are more different than they are alike.

\footnotetext{
${ }^{1}$ Johan Fornäs. "Europe Faces Europe: An Introduction." In Europe Faces Europe: Narratives from Its Eastern Half, edited by Johan Fornäs, 3. Bristol/Chicago: Intellect, 2017.

${ }^{2}$ Richard K. Hermann et. al. Transnational Identities: Becoming European in the EU. (Lanham: Rowman \& Littlefield Publishers Inc., 2004), 217.

${ }^{3}$ Ibid., 215

${ }^{4}$ Johan Fornäs. "Europe Faces Europe: An Introduction.” In Europe Faces Europe: Narratives from Its Eastern Half, edited by Johan Fornäs, 5. Bristol/Chicago: Intellect, 2017; Sébastien Bourdin. "A Geographical Approach to Economic Convergence. Exploring Regional Disparities in the European Union and Their Evolution." L'Espace Géographique (English Edition) 42, no. 3 (2013): 257.
} 
In the past, the EU acted as a unifying force for the continent and ultimately set out to create a Europe that was unified in its goals and culture. However, the EU's apparent unity only exists at the surface level; underlying tensions and issues, most notably the contention between national identity and European identity, demonstrate that the EU is not as unifying of a force as its founders designed it to be. There are numerous examples of the EU member states being at odds with one another. When the United States invaded Iraq in 2003, Europe did not respond with one voice. Instead, the United Kingdom backed the United States while the rest of the EU member states were against any kind of military action in Iraq. ${ }^{5}$ The EU has also created great divides between businesses in Europe and individual citizens, with many arguing that the EU cares more for the prosperity of its businesses than it does for the prosperity of its citizens. ${ }^{6}$ This is only one example from nearly 20 years ago, but the fact that the EU was unable to produce a unified response in a time when none of the current populist and nationalist forces were as vocal suggests that the EU had unstable foundations for some time.

In more recent times, protesters in oppressive non-EU states have united behind the EU values of democracy and freedom, making the EU a symbol of their desired future. In Ukraine in 2013, protesters took to the streets demanding change in the form of integration into the EU. Protestors paraded the European flag and demonstrated their desire for their country to align with values espoused by the EU. While non-member European countries unite behind the EU, there appears to be a growing rift between EU member states. Although the EU has removed the physical borders between its member states, numerous figurative borders have cropped up, ${ }^{7}$ such as the urban-rural divide. Urban centres have greater social mobility and economic growth, providing greater opportunities for urban populations than those in rural areas. ${ }^{8}$ Arguably, these emerging divisions are more of a threat to European unity than any physical border.

Socioeconomic disparities could lead to public disillusionment with the EU leaders and suspicion

\footnotetext{
${ }^{5}$ Hermann et. al. Transnational Identities, 215; it is interesting to note that Poland also joined the USBritain coalition in Iraq while it was in the final stages of its accession to the EU. This move to go against the official position of the EU had seemingly no impact on its ability to gain membership on 1 May 2004.

${ }^{6}$ Katrin Bennhold. "What is Europe? Freedom, Slavery, Austerity or Nothing at All," The New York Times, 22 May 2019.

${ }^{7}$ Hermann et. al. Transnational Identities, 215.

${ }^{8}$ Sorin Petrica Angheluta, Marcela Antoneta Mitrita, Raluca Iuliana Georgescu, and Cristina Dima. "Characteristics of Education and Employment in European Urban Areas." Theoretical and Empirical Researches in Urban Management 14, no. 4 (2019): 87.
} 
that they do not have people's best interests at heart. These new borders have divided Europe in unprecedented ways and brought to light the issue of unity within Europe.

\section{Christianity and the "Othering" of Turkey}

The challenges of Turkish accession highlight two necessary features that would qualify a country as "European": liberal democracy and Christianity. ${ }^{9}$ While democracy is an explicit requirement for EU membership and one of the four pillars upon which the EU was built, Christianity is more of an implicit requirement. Though the EU is technically a secular union, all the member states have a history of Christianity. Christianity is not only a unifying force among member states but is also the basis for the values upon which the EU rests. ${ }^{10}$ Even if Turkey could reform its democratic processes, its large Muslim population would likely act as a deterrent to full membership. ${ }^{11}$ The EU is a de facto 'Christian club' and has demonstrated this identity by drawing out negotiations with Turkey and outright rejecting advances made by Morocco. ${ }^{12}$ Critics might argue that these countries have been omitted because they are not European enough. However, without a concrete definition of Europeanness, it is evident that the real reason might be their lack of Christianity. ${ }^{13}$ Prior to becoming European Council President in 2009, Herman Van Rompuy was quoted saying: "Turkey is not a part of Europe and will never be part of Europe [...] The universal values which are also fundamental values of Christianity, will lose vigour with the entry of a large Islamic country such as Turkey." ${ }^{14}$ Countries with a Muslim minority do not present the same issues as Turkey. These minority populations do not have the size and power to impact policy, making them less of a concern. Van Rompuy's 2009 statement highlights the fact that the size of Turkey's Muslim population is a great concern to those who oppose Turkish accession. The fact that the "universal values" of European identity are also considered to be Christian values only further suggests that Turkey's lack of Christianity is one of the largest factors barring its accession to the EU.

\footnotetext{
${ }^{9}$ Barry Rubin, Ali Çarkoglu. Turkey and the European Union: Domestic Politics, Economic Integration and International Dynamics. (New York: Frank Cass and Company Limited: 2005), 10; Kerim Yildiz. The European Union and Turkish Accession: Human Rights and the Kurds. (London: Pluto Press, 2008), 27.

${ }^{10}$ Münevver Cebeci. "Deconstructing the EU's "Standards of Civilisation"- The Case of Turkey." Uluslararası İlişkiler / International Relations 16, no. 64 (2019), 85.

${ }^{11}$ Yildiz, Human Rights and the Kurds, 25.

12 John Redmond. "Turkey and the European Union: Troubled European or European Trouble?" International Affairs (Royal Institute of International Affairs 1944-) 83, no. 2 (2007): 313-314.

${ }^{13}$ Ibid., 314.

${ }^{14}$ Cebeci. "Deconstructing the EU's "Standards of Civilisation"”, 85.
} 
In the years immediately following World War II, there was an inextricable link between religion and integration. The partnership for the Inner Six was certainly one of economic benefit, but they also aligned very closely on their religious beliefs. ${ }^{15}$ Their link to Catholicism provided a basis for unity for them that was, in many ways, easily identifiable. Religion also plays a large role in modern European politics. Parties have taken on religious symbolism or included "Christianity" in their names or mottos to show their commitment to Christian values. ${ }^{16}$ This is not to say that there have not been debates surrounding the EU's link to religion. However, these debates have not highlighted the typical argument for the separation of Church and state. Instead, they have largely focused on the EU's commitment to Catholicism over Protestantism, or vice versa. ${ }^{17}$ This commitment to Christianity demonstrates the EU's unwillingness to depart from Christian values and, as an extension, to make space for other religions such as Islam. This commitment to Christianity manifests itself in several ways. In Switzerland, for example, the construction of minarets on Mosques was banned. Although Switzerland is not an EU member, it is an unquestioningly European state and thus demonstrates the broad European commitment to Christianity. In France, former president Nicolas Sarkozy banned the wearing of head scarves by Muslim women in French schools. ${ }^{18}$ These are only a couple of examples of religious intolerance in Europe from a long history of valuing Christianity over all other religions.

For much of the latter half of the twentieth century, the Soviet Union was an "other" in Europe, and in many ways since its dissolution, Turkey has adopted that role. According to the EU, there are several concerns about Turkey's inability to fit the European mold insofar as Turkish identity is inconsistent with European identity. If granted membership into the EU, Turkey would be the only Muslim majority country in a union that has traditionally been considered an exclusive Christian club. ${ }^{19}$ An additional factor driving hesitation towards Turkey is the East/West divide that has plagued Europe since Winston Churchill gave his Iron Curtain speech in 1946. This narrative portrays the divide as an inherent and even necessary part of

\footnotetext{
${ }^{15}$ Brent F. Nelsen, James L. Guth, and Cleveland R. Fraser. "Does Religion Matter?- Christianity and Public Support for the European Union.” European Union Politics 2, no. 2 (June 2001), 193.

${ }^{16}$ Ibid.

${ }^{17}$ Ibid.

${ }^{18}$ Alan Arwin, and Lawrence Mayer. "Tolerance and the Politics of Identity in the European Union." Social Science Quarterly 95, no. 3 (2014): 671.

${ }^{19}$ Yildiz, Human Rights and the Kurds, 27.
} 
Europe. ${ }^{20}$ The divide is as much about geopolitics as it is about what Münevver Cebeci calls the "civilization-barbarism dichotomy." 21 This dichotomy presents Western European countries, and by extension the EU, as the civilized people who must help civilize the rest of Europe. Throughout history, Turks have been the Eastern "other." As quoted in Tim Jcoby's article Turkey and Europe: Culture, Capital and Corruption, "King Christian I of Denmark (14261481) [...] considered the Turk to be 'the beast rising out of the seas described in the Apocalypse." ${ }^{22}$ More recently, in 2005, Pope Benedict XVI addressed his first general audience by reaffirming that the irrefutable root of European culture and civilization is Christianity. ${ }^{23}$ Combined with the comments made by Van Rompuy and policies enacted by Sarcozy, this only further highlights Turkey as an "other" that would upend the already delicate balance of the EU.

\section{Turkey as a Strategic Ally}

Turkey applied for EU membership on 14 April 1987 and has since proven its dedication to becoming a full EU member state. ${ }^{24}$ In the years since its application, Turkey has joined a Customs Union with the EU, been officially recognized as a candidate for accession, made 34 constitutional amendments in one year which were aimed at meeting the EU's criteria for membership, removed the death penalty, and in 2005 began formal accession negotiations with the EU. ${ }^{25}$ This seemingly exhaustive list of changes that Turkey made to fit the EU model has failed to gain them membership. In most accession negotiations, the EU sets a timeline for membership. In the case of Turkey, the EU made sure to leave negotiations open-ended with the option for the EU to suspend negotiations whenever it felt Turkey was not doing enough. ${ }^{26}$ With this option on the table, the EU entered the negotiations with the mindset that they would be suspending them at some point. Between its application in 1987 and the beginning of official accession negotiations, Turkey worked tirelessly to prove its dedication to EU membership

${ }^{20}$ Stefan Jonsson. "Clashing Internationalisms: East European Narratives of West European Integration.” In Europe Faces Europe: Narratives from Its Eastern Half, edited by Johan Fornäs, 65. Bristol/Chicago: Intellect, 2017.

${ }^{21}$ Münevver Cebeci. "Deconstructing the EU's "Standards of Civilisation"- The Case of Turkey." Uluslararası İlişskiler / International Relations 16, no. 64 (2019), 77-91.

22 Tim Jacoby. "Turkey and Europe: Culture, Capital and Corruption." Review of International Studies 36, no. 3 (2010): 665-666.

${ }^{23}$ Ibid., 666-667.

${ }^{24}$ Barry Rubin, Ali Çarkoglu, Domestic Politics, 5.

${ }^{25}$ Ibid., 5-14.

${ }^{26}$ Yildiz, Human Rights and the Kurds, 25. 
through democratization. Thus, it is evident that EU members want to keep negotiations open to maintain Turkish engagement without any real intention to advance the negotiations. ${ }^{27}$ This is not to say that Turkey has met all necessary requirements; however, it is clear that even in cases where they made great progress, negotiations remained stalled. This allows for the EU to balance its strategic need for Turkey with its desire to keep the EU culturally homogenous and Christian.

Turkey is supposedly a bridge between Europe, Asia, and the Middle East. However, despite its invaluable position to the EU as a stabilizer in the region, accession negotiations have continued for 14 years with no end in sight. ${ }^{28}$ Turkey is extremely important for European strategic goals, as evidenced by Turkey's role in NATO. ${ }^{29}$ Turkey's role as a strategic ally was clear in its role in the 2011 Arab Spring. During that time, Turkey showed commitment to both the region and to the EU. ${ }^{30}$ Perhaps inadvertently, this unwillingness to move away from Europe demonstrated to the EU that despite no progress being made in Turkish accession, Turkey remained a reliable ally in the Middle East. However, Turkey has since militarily intervened in Northern Syria, calling into question Turkey's role as an ally to the EU in the Middle East. In the months leading up to the 2019 operation, Turkish President Recep Tayyip Erdogan stated that Turkey would stay in Syria "until [Turkey was] done," a vague statement that had some experts concerned that this would translate into annexation or perhaps an attempt at rebuilding the empire. ${ }^{31}$ Turkey has the power to help the EU achieve its strategic goals in the Middle East, but its recent involvement in Syria demonstrates that it is also willing to work against the EU's strategic goals if it is in its best interest.

The EU unfairly expects Turkey to solve its problems in the Middle East for them. The Kurdish issue in Turkey is a direct result of Europe's inability to provide the Kurds with their promised independent Kurdistan, as outlined in the Treaty of Sevres in 1920. ${ }^{32}$ Europe has not fulfilled its commitments to Kurdish independence and has instead punished Turkey for its inability to adequately deal with the situation. This is not to say that Turkish human rights violations against the Kurds are acceptable, but it does highlight the fact that Europe bears some

${ }^{27}$ Asli Aydintasbas. Report. European Council on Foreign Relations, 2018, 2.

${ }^{28}$ Yildiz, Human Rights and the Kurds, 27.

${ }^{29}$ Turkay Yildiz. The European Union and Turkey: A Review of their Commonalities and Disparities, 53.

${ }^{30}$ Rahime Süleymanoglu-Kürüm. Conditionality, the EU, and Turkey: From Transformation to Retrenchment. (New York: Routledge, 2019), 71.

${ }^{31}$ Engin Yüksel, and Erwin Van Veen. Report. Clingendael Institute, 2019, 10.

${ }^{32}$ Yildiz, Human Rights and the Kurds, 170. 
responsibility in this issue and should be working earnestly with Turkey to find a solution. The EU has been trying to balance its strategic need for Turkey with its fears of what Turkish membership would mean for the Union as a whole. This balancing act proves difficult and, in many ways, pushes Turkey eastward. ${ }^{33}$ More specifically, it appears as though Turkey is willing to align itself with Russia, a direct result of Russia's support for Turkish President Erdogan following the 2016 coup attempt. ${ }^{34}$ This is not to say that the relationship between Turkey and Russia is uncomplicated. There are many areas in which they find themselves at odds, particularly when it comes to the Kurds in Syria. ${ }^{35}$ However, rapprochement since 2016 has demonstrated that Turkey is willing to align itself strategically with Russia whenever beneficial to its strategic goals. ${ }^{36}$ Turkey has begun to take a more pragmatic approach toward the EU, recognizing that it needs to prioritize national interests over meeting requirements that may or may not secure it membership. If accession negotiations were to break down completely and Turkey were to turn toward the East, the EU would lose an important strategic partner and regional stabilizer. Despite the EU's inability to reconcile its need for and fear of Turkey, Turkey remains committed to EU membership. ${ }^{37}$ Perhaps both sides see the necessity of engaging in accession negotiations to meet their own strategic goals.

\section{Troubling Trends in Europe}

The 2019 European Election results signaled demands for change from the electorate. The two traditional leaders of the European Parliament, the Progressive Alliance of Socialists and Democrats (S\&D) and the European People's Party (EPP) lost 45 and 41 seats, respectively. ${ }^{38}$ Their combined losses mean that their coalition no longer holds the majority in Parliament. The loss, however, is not necessarily concerning to the EU as a whole. An overwhelming majority, or $75 \%$, of voters supported pro-European parties. ${ }^{39}$ At the national

${ }^{33}$ Süleymanoglu-Kürüm. Conditionality, the EU, and Turkey, 58.

${ }^{34}$ Dimitar Bechev, et. al. Russia's Return to the Middle East: Building Sandcastles? Report. Edited by Popescu Nicu and Secrieru Stanislav. European Union Institute for Security Studies (EUISS), 2018. 97.

35 Şener Aktürk. "Relations between Russia and Turkey Before, During, and After the Failed Coup of 2016." Insight Turkey 21, no. 4 (2019): 97.

36 Ibid., 98. 2019.

${ }^{37}$ Zeynep Atilgan. "No New Phase Seen in EU-Turkey Relations After EP Elections,” Euractiv, 31 May May 2019

\footnotetext{
${ }^{38}$ Jon Henly. "Five Things We Have Learned From the Elections Across Europe," The Guardian, 27
}

${ }^{39}$ Jason Horowitz, "Election Puts Europe on the Front Line of the Battle With Populism," The New York 
level, however, far-right nationalist parties saw great victories in France, Italy, and other countries. ${ }^{40}$ While these parties do not have the capacity to drive dramatic policy changes within the EU, populist parties can steer the conversation and shift public perception around what the EU means for national identities. ${ }^{41}$ Populist movements function by suggesting not only that elected officials do not represent the will of the people but also that they actively seek to undermine said will. ${ }^{42}$ In an age when they feel disillusioned by traditional politicians, citizens are receptive to populist messages. Populist rhetoric is divisive and threatens the future of the EU and its open borders. They campaign against the bureaucracy, "do-gooders, bankers, and migrants," and promise insurgency across Europe. ${ }^{43}$ With voter turnout up $8 \%$ in the recent election, Europeans seem more invested in European politics and those who have been vying for EU membership face more uncertainty.

Hesitation towards Turkish accession has to do in large part with the implications of having a member state that has a large Muslim majority. When Turkey first expressed interest in becoming a member of the EU, member states responded with indecision, ${ }^{44}$ which seemed to set the tone for the entirety of the negotiations. However, uncertainty was not unwarranted as much of Turkey's history is inconsistent with European values. ${ }^{45}$ Turkey is projected to have the largest population out of the EU member states by the year 2025. This large population, if granted membership, would give Turkey the greatest number of votes in the European council. ${ }^{46}$ Member states are concerned that Turkey is not European enough to have such decision-making power. Angela Merkel has been vocal in her opposition to Turkish accession, saying that she is concerned about Turkish identity and the potential influx of Turkish immigration. ${ }^{47}$ Another

Times, 27 May 2019.

${ }^{40}$ Steven Erlanger. "European Election Results Show Growing Split Over Union's Future,” The New York Times, 26 May 2019.

41 Ibid.

${ }^{42}$ Gandesha, Samir. "Understanding Right and Left Populism." In Critical Theory and Authoritarian Populism, edited by Morelock Jeremiah, 50. London: University of Westminster Press, 2018.

${ }^{43}$ Steven Erlanger. "European Election Results Show Growing Split Over Union's Future," The New York Times, 26 May 2019.

${ }^{44}$ Emiliano Alessandri, Ian Lesser, and Kadri Tastan. Report. German Marshall Fund of the United States, 2018,7 .

${ }^{45}$ Demet Yalcin Mousseau. "Democracy, Human Rights and Market Development in Turkey: Are They Related?" Government and Opposition 41, no. 2 (2006): 308.

46 Yildiz, Human Rights and the Kurds, 25.

${ }^{47}$ Ibid; when speaking about Turkish immigration, Angela Merkel was referring to the fact that Turkey joining the EU would open up borders between Turkey and Europe allowing Turkish citizens free mobility throughout Europe, allowing them to relocate wherever they may please. 
vocal opponent to Turkish accession is former French President Nicolas Sarkozy. He repeatedly opposed Turkey's accession, saying that Turkey was geographically and culturally nonEuropean. ${ }^{48}$ This is not a concern that has been expressed about existing member states and raises questions about why there is so much concern regarding immigration from Turkey. The United Kingdom was Turkey's biggest supporter, which may cause Turkey to lose a champion within the EU in the context of Brexit. ${ }^{49}$ The clear issue that member states have with Turkish accession is not that Turkey has not made the effort to meet membership requirements, but that Turkey does not fit the European mold. Essentially, Turkish identity does not match up with the ever changing and ambiguous "homogenous" European identity.

\section{Turkey's Shortcomings}

Human rights violations in Turkey are one of the main drivers of opposition to Turkish accession. However, there appears to be a double standard when it comes to violations committed by Turkey and violations committed by EU member states. The EU noted that while Turkey made important policy changes, they did not translate into meaningful change within the nation. A key example is the eradication of torture. While theoretically an important sign of progress, there remain countless situations where torture is used in Turkey, which violates the EU's policy on human rights. ${ }^{50}$ It appears as though Turkey continues to make changes that appear to align with European values de jure but not de facto. Between the treatment of the Kurds, the use of the death penalty, and the use of torture, EU member states are reluctant to believe that Turkey is as prepared for EU membership as it claims to be. ${ }^{51}$ The combination of Turkey's human rights violations and its Muslim majority deprioritizes the prospect of Turkish membership in the eyes of the EU.

While Turkey is the only current or prospective member state with a Muslim majority, it is not the only one with a questionable human rights record. There are member states who have been back-sliding on human rights issues but met with a deafening silence from the EU. ${ }^{52}$ For

\footnotetext{
(2009): 82.

${ }^{48}$ Tsilla Hershco. "Sarkozy's Policy in the Middle-East: A Break with the Past?" Insight Turkey 11, no. 2 2019.

${ }^{49}$ Zeynep Atilgan. "No New Phase Seen in EU-Turkey Relations After EP Elections,” Euractiv, 31 May

${ }^{50}$ Yildiz, Human Rights and the Kurds, 31.

${ }^{51}$ Ibid., 21.

${ }^{52}$ Emiliano Alessandri, Ian Lesser, and Kadri Tastan. Report. German Marshall Fund of the United States,
} 2018,8 . 
years, Human Rights Watch has reported egregious violations of human rights in Hungary. The situation was so severe that in October 2018, Human Rights Watch published a report calling for the EU to take strong action against Hungary and prove that they will not stand for back-sliding on EU values. ${ }^{53}$ However, since the publication of the report, the EU and its member states have done very little to condemn Hungary for these violations, even as Human Rights Watch published a report in June 2019 once again calling out Hungary for its human rights violations. ${ }^{54}$ In late 2018, Human Rights Watch also reported on the human rights violations of Bulgaria and Poland. ${ }^{55}$ Turkey differs from these countries in that it is not an EU member state. It is therefore important to recognize the fact that the $\mathrm{EU}$ is willing to turn a blind eye to the violations of member states while doubling down on those of Turkey, because it further reinforces the notion that the EU's reluctance towards Turkish accession has more to do with Turkish culture and identity than its shortcomings as a democratic nation.

Furthermore, the EU's continued positive relations with Turkey severely undermine its outrage over the human rights violations towards the Kurds. The EU condemned Saddam Hussein's treatment of the Iraqi Kurds while having positive relations with Turkey. In this situation, the EU demonstrates that it will only address and condemn human rights violations if such action does not alienate allies or detract from strategic goals. ${ }^{56}$ Iraq did not hold strategic value for the EU and thus condemnation of Saddam Hussein's actions was swift. However, the EU cannot sour its relationship with Turkey as they rely on the country for regional stability. While the EU claims to be incredibly concerned about human rights violations and minority rights in Turkey, very little action is taken to ensure these rights are protected. ${ }^{57}$ Based on inconsistencies in the EU's approach to Turkey, one could argue that the condemnation of Turkey's human rights violations is a convenient way to bar Turkey from accession without admitting its bias against the country's Muslim majority.

Turkey's unmoving position on Cyprus has also been cited as a key obstacle to its EU membership. Cyprus is an island in the Mediterranean made up of a large Greek majority and a

53 "EU: Oppose Hungary's Rejection of EU Values," Human Rights Watch, 15 October 2018.

${ }^{54}$ Ibid.

${ }^{55}$ Ibid.

${ }^{56}$ Yildiz, Human Rights and the Kurds, 171-172.

${ }^{57}$ Edel Hughes. "The European Union Accession Process- Ensuring the Protection of Turkey's Minorities?" International Journal on Minority and Group Rights 17, no. 4 (2010), 565, 567. 
small Turkish minority in the North. ${ }^{58}$ Following its declaration of independence, Cyprus instituted a constitution that was meant to curtail any ethnic conflict. This constitution outlined a power-sharing structure that allowed for proportional representation of both ethnic groups, more specifically, a Greek Cypriot president, a Turkish Cypriot vice-president, four Greek Cypriot ministers, and three Turkish Cypriot minister. ${ }^{59}$ However, that proved to be unsuccessful as Greek Cypriots continually harassed Turkish Cypriots, which led to the withdrawal of Turkish Cypriots from governmental institutions and the establishment of armed enclaves in selfdefence. ${ }^{60}$ Events culminated in a coup led by the Greeks in 1974 which in turn led to military intervention by Turkey, creating the Turkish Republic of Northern Cyprus. ${ }^{61}$ Turkey has refused to recognize the Republic of Cyprus, only acknowledging the Turkish Republic of Northern Cyprus which is made up of Turkish Cypriots. ${ }^{62}$ The issue of recognition highlights Turkey's desire to unite Cyprus with Turkey rather than Greece despite the large Greek population on the island. So long as Turkey refuses to recognize the Republic of Cyprus, Greece will not support Turkish membership and accession negotiations will remain at a standstill. Much like with the Kurdish issue, the EU's continued positive relations with Turkey despite its support for the Republic of Northern Cyprus and military intervention stands to demonstrate how the EU is only willing to be critical enough to appear to be tough on Turkey while otherwise working to maintain a positive relationship with them.

\section{Conclusion}

The EU's motto is "United in diversity," yet the challenges of Turkish accession call into question the kind of diversity to which the EU is committed. ${ }^{63}$ While the EU cites Turkey's shortcomings as the reason for its delayed membership, the reality of the situation appears to be that the EU is reluctant to allow entry to a country that does not fit the European mold. With a more European identity, perhaps the EU would consider Turkey's application more seriously.

\footnotetext{
${ }^{58}$ Nation, R. Craig. War in the Balkans, 1991-2002. Report. Strategic Studies Institute, US Army War College, 2003. 289.

${ }^{59}$ Ibid., 290.

${ }^{60}$ Ibid., 291.

${ }^{61}$ Ibid., 292.

${ }^{62}$ Barry Rubin, Ali Çarkoglu, Domestic Politics, 14.

${ }^{63}$ Johan Fornäs. "Europe Faces Europe: An Introduction.” In Europe Faces Europe: Narratives from Its Eastern Half, edited by Johan Fornäs, 4. Bristol/Chicago: Intellect, 2017.
} 
However, with a strategic need for Turkey, the EU maintains seemingly positive relations without committing to Turkish membership.

Turkey entered accession negotiations with the EU in 2005. Since then it has faced increasing challenges to achieve membership. The futility of Turkish accession negotiations has less to do with Turkey's inability to meet the requirements outlined by the EU and more to do with identity and culture, issues that were highlighted in the 2019 European Elections. To prove this assertion, this paper analyzed the role of the "homogenous" European identity in Turkish accession negotiations, the EU's scrutiny of Turkey's human rights record while turning a blind eye to countries like Hungary, Bulgaria, and Poland, the ever-present tug-of-war between hope and disillusionment, and the ways in which EU elections will shape the future of Turkish accession negotiations. 


\section{Bibliography}

Alessandri, Emiliano, Ian Lesser, and Kadri Tastan. Report. German Marshall Fund of the United States, 2018.

Angheluta, Sorin Petrica, Marcela Antoneta Mitrita, Raluca Iuliana Georgescu, and Cristina Dima. "Characteristics of Education and Employment in European Urban Areas." Theoretical and Empirical Researches in Urban Management 14, no. 4 (2019): 86-94.

Arwine, Alan, and Lawrence Mayer. "Tolerance and the Politics of Identity in the European Union." Social Science Quarterly 95, no. 3 (2014): 669-81.

Aktürk, Şener. "Relations between Russia and Turkey Before, During, and After the Failed Coup of 2016." Insight Turkey 21, no. 4 (2019): 97-114.

Atilgan, Zeynep. "No New Phase Seen in EU-Turkey Relations After EP Elections," Euractiv, 31 May 2019.

Aydintasbas, Asli. Report. European Council on Foreign Relations, 2018.

Barry Rubin, Ali Çarkoglu. Turkey and the European Union: Domestic Politics, Economic Integration and International Dynamics. New York: Frank Cass and Company Limited, 2005.

Bechev, Dimitar, et. al. Russia's Return to the Middle East: Building Sandcastles? Report. Edited by Popescu Nicu and Secrieru Stanislav. European Union Institute for Security Studies (EUISS), 2018. 95-102.

Bennhold, Katrin. "What is Europe? Freedom, Slavery, Austerity or Nothing at All," The New York Times, 22 May 2019.

Bourdin, Sébastien. "A Geographical Approach to Economic Convergence. Exploring Regional Disparities in the European Union and Their Evolution." L'Espace Géographique (English Edition) 42, no. 3 (2013): 256-70.

Cebeci, Münevver. "Deconstructing the EU's "Standards of Civilisation"- The Case of Turkey." Uluslararası İlişkiler / International Relations 16, no. 64 (2019): 77-91.

Erlanger, Steven. "European Election Results Show Growing Split Over Union's Future," The New York Times, 26 May 2019.

“EU: Oppose Hungary’s Rejection of EU Values,” Human Rights Watch, 15 October 2018.

Fornäs, Johan. "Europe Faces Europe: An Introduction.” In Europe Faces Europe: Narratives from Its Eastern Half, edited by Johan Fornäs, 1-34. Bristol/Chicago: Intellect, 2017. 
Gandesha, Samir. "Understanding Right and Left Populism." In Critical Theory and Authoritarian Populism, edited by Morelock Jeremiah, 49-70. London: University of Westminster Press, 2018.

Henly, Jon. "Five Things We Have Learned From the Elections Across Europe," The Guardian, 27 May 2019.

Hershco, Tsilla. "Sarkozy's Policy in the Middle-East: A Break with the Past?" Insight Turkey 11, no. 2 (2009): 75-91.

Hughes, Edel. "The European Union Accession Process- Ensuring the Protection of Turkey's Minorities?" International Journal on Minority and Group Rights 17, no. 4 (2010): 56177.

Jacoby, Tim. "Turkey and Europe: Culture, Capital and Corruption." Review of International Studies 36, no. 3 (2010): 663-84.

Jonsson, Stefan. "Clashing Internationalisms: East European Narratives of West European Integration." In Europe Faces Europe: Narratives from Its Eastern Half, edited by Johan Fornäs, 72-101. Bristol/Chicago: Intellect, 2017.

Mousseau, Demet Yalcin. "Democracy, Human Rights and Market Development in Turkey: Are They Related?" Government and Opposition 41, no. 2 (2006): 298-326.

Nation, R. Craig. War in the Balkans, 1991-2002. Report. Strategic Studies Institute, US Army War College, 2003.

Nelsen, Brent F., James L. Guth, and Cleveland R. Fraser. "Does Religion Matter?- Christianity and Public Support for the European Union.” European Union Politics 2, no. 2 (June 2001): 191-217.

Redmond, John. "Turkey and the European Union: Troubled European or European Trouble?" International Affairs (Royal Institute of International Affairs 1944-) 83, no. 2 (2007): 305-17.

Richard K. Hermann et. al. Transnational Identities: Becoming European in the EU. Lanham: Rowman \& Littlefield Publishers Inc., 2004.

Süleymanoglu-Kürüm, Rahime. Conditionality, the EU, and Turkey: From Transformation to Retrenchment. New York: Routledge, 2019.

Yildiz, Kerim. The European Union and Turkish Accession: Human Rights and the Kurds. London: Pluto Press, 2008.

Yüksel, Engin, and Erwin Van Veen. Report. Clingendael Institute, 2019. 